(например, для оформления принятия в состав РФ Республики Крым и города Севастополь).

В связи с изложенным, термин «государственные интересы» является более универсальным и точным, нежели «национальные интересы». Во-первых, национальный характер интересов может быть выражен только в демократических государствах и не в полной мере. Во-вторых, конкретные субъекты принятия решений (как в демократических, так и недемократических государствах), выражают не только национальные, но и собственные, корпоративные интересы. Кроме того, сложно выражать интересы нации в целом, если она является разнородной и не имеет общего согласованного интереса.

Таким образом, можно определить государственные интересы как совокупность конкретных общественно значимых потребностей и желаний государственной власти на текущий момент времени, получающих абстрактную или фрагментарную формализацию в правовых актах.

$$
* * *
$$

1. Государство, общество, личность: проблемы совместимости/ Под общ. ред Р.А. Ромашова, Н.С. Нижник.М.: Юристь, 2005. С. 130

2. Гуния А.А. понятие «государственного интереса» и специфика его проявления в деятельности государственных корпораций в Российской Федерации // Право и государство: теория и практика. 2011. № 3. C. 123.

3. Малик Е.Н., Жихорев Е.Г. Национально-государственные интересы современной России: приоритеты обеспечения в условиях информатизации политики// Среднерусский вестник общественных наук. 2016. Т. 11. № 5. C. 121-128.

4. Муратшин Т.Ф. Национально-государственные интересы: сущность и характерные черты // Вестник БИСТ . № 4. -2017 C. 139.

5. Титенко Ю.В. Соотношение понятий «национальный интерес», «государственный интерес» // Вестник чеченского государственного университета. № 2. - 2019. С. 127.

\title{
Бредихин А.Л., Фомичев С.М. \\ Защита интересов бизнеса при выявлении незаконного привлечения иностранного гражданина к трудовой деятельности
}

Санкт-Петербургский университет МВД России (Россия, Санкт-Петербург)

doi: 10.18411/trnio-10-2021-111

\section{Аннотация}

В настоящей статье автор рассматривает некоторые аспекты уязвимости прав субъектов предпринимательства при выявлении правонарушений, связанных с незаконным привлечением к трудовой деятельности мигрантов, предлагает возможные варианты изменения законодательства.

Ключевые слова: миграция, незаконная трудовая деятельности, защита бизнеса, административная ответственность.

\section{Abstract}

In this article, the author examines some aspects of the vulnerability of the rights of business entities when identifying offenses related to the illegal involvement of migrants in labor activity, and suggests possible options for changing the legislation.

\section{responsibility.}

Keywords: migration, illegal labor activity, business protection, administrative

Несмотря на негативное отношение граждан России к мигрантам, нужно сказать, что современная экономика страны не может обойтись без трудовых мигрантов. Особенная нужда в иностранных рабочих имеется там, где необходимо выполнять 
низкоквалифицированную работу, а также работу в тяжелых условиях труда и в труднодоступной местности.

Ответственность за незаконное привлечение к трудовой деятельности иностранных граждан установлена ст. 18.15 Кодекса об административных правонарушениях. Привлечением к трудовой деятельности в Российской Федерации иностранного гражданина или лица без гражданства понимается допуск в какой-либо форме к выполнению работ или оказанию услуг либо иное использование труда иностранного гражданина или лица без гражданства.

Часть 1 статьи 18.15 КоАП РФ предусматривает штраф на юридических лиц - от двухсот пятидесяти тысяч до восьмисот тысяч рублей либо административное приостановление деятельности на срок от четырнадцати до девяноста суток.

Объективная сторона правонарушения состоит в:

- привлечении к трудовой деятельности в Российской Федерации иностранного гражданина или лица без гражданства при отсутствии у этих иностранного гражданина или лица без гражданства разрешения на работу либо патента, если такие разрешение либо патент требуются в соответствии с федеральным законом;

- привлечение к трудовой деятельности в Российской Федерации иностранного гражданина или лица без гражданства по профессии (специальности, должности, виду трудовой деятельности), не указанной в разрешении на работу или патенте, если разрешение на работу или патент содержит сведения о профессии (специальности, должности, виде трудовой деятельности);

- привлечение иностранного гражданина или лица без гражданства к трудовой деятельности вне пределов субъекта Российской Федерации, на территории которого данному иностранному гражданину или лицу без гражданства выданы разрешение на работу, патент или разрешено временное проживание;

- неуведомление или нарушение установленного порядка и (или) формы уведомления территориального органа федерального органа исполнительной власти, осуществляющего федеральный государственный контроль (надзор) в сфере миграции, о заключении или прекращении (расторжении) трудового договора или гражданско-правового договора на выполнение работ (оказание услуг) с иностранным гражданином в срок, не превышающий трех рабочих дней с даты заключения, прекращения (расторжения) договора, если такое уведомление требуется в соответствии с федеральным законом.

Если правонарушение совершено в городе федерального значения Москве или СанктПетербурге либо в Московской или Ленинградской области часть 4 этой статьи предусматривает штраф на юридических лиц - от четырехсот тысяч до одного миллиона рублей либо административное приостановление деятельности на срок от четырнадцати до девяноста суток. При этом, назначается штраф из расчета на каждый случай незаконного привлечения к трудовой деятельности. То есть, размер штрафа увеличивается пропорционально количеству незаконно привлеченных работников.

Таким образом, штрафы очень значительные и неподъемные для многих предприятий малого и среднего бизнеса.

С одной стороны это должно побуждать работодателя соблюдать законодательство и выполнять все правила и условия привлечения иностранных работников. Однако, на практике не так все однозначно, поэтому хотелось бы обратить внимание на уязвимость бизнеса в этой сфере.

Во-первых, нужно отметить, что не все предприниматели (особенно если это субъекты малого предпринимательства) могут себе позволить принимать в штат 
иностранных работников, проверять и контролировать правильность оформления разрешительных документов на осуществление трудовой деятельности. Бывают случаи, когда предполагаемый работник предоставляет подложные документы при устройстве на работу. Однако, ответственность за привлечение такого работника наступит у работодателя, т.к. мигрант допущен к работе без соответствующих оснований. То обстоятельство, что документы были подложные не будет основанием для освобождения от ответственности, так как работодатель должен был проверить их.

Во-вторых, в настоящее время довольно много коммерческих организаций, предоставляющих работников на договорной основе для выполнения тех или иных работ (т.н. аутсорсинг). Для работодателя это выгодно, т.к. избавляет от лишних функций и разгружает работу кадровой службы. Вместе с тем, ввиду ужесточения требований к осуществлению аутсорсинговой деятельности в чистом виде, сейчас чаще всего нелицензированные компании предоставляют персонал под видом договоров услуг, где прописываются работы, которые должны выполняться без акцента на предоставление именно работников и без указание их имен.

Наряду с определенной выгодой, фактический работодатель несет и множество рисков. Так, довольно часто кадровые агентства недостаточно грамотно проверяют наличие права на работу у иностранных граждан, либо сознательно допускают к работе лиц, не имеющих на это право. Предприятие, на территории которого эти мигранты непосредственно осуществляют трудовую деятельность, не всегда может отследить наличие либо отсутствие права на работу у этих лиц.

В случае проведения проверки объекта работодателя, могут быть обнаружены иностранные граждане, без соответствующим образом оформленных документов, дающих право на работу. Благоприятный для работодателя исход возможен только в том случае, если этот работник оформлен в штат кадрового агентства и он может предоставить соответствующие документы. В противном случае, ответственность будет нести работодатель на территории или в непосредственном подчинении которого находились эти работники.

Например, на практике часто складывается следующая ситуация. Правоохранительные органы задерживают работника (например, уборщик) на территории предприятия или прилегающей территории, тот не владеет русским языком, не имеет при себе документов, дающих право на работу. В отношении него возбуждается дело об административном правонарушении, он привлекается к ответственности и подлежит депортации. При этом, установленные при производстве административного и судебного разбирательства обстоятельства, автоматически образуют состав административного правонарушения и для предприятия. Доказывать отсутствие вины предпринимателя крайне затруднительно. В итоге предприятие получает крупный штраф, а если таких задержанных мигрантов несколько, то еще и в кратном размере.

Таким образом, следует отметить важность борьбы с незаконной трудовой миграцией. Надлежащим образом оформленные документы, дающие право на работу иностранному гражданина, не только предотвращают привлечение к административной ответственности непосредственного работодателя, но и защищают интересы самого мигранта. Между тем, на практике зачастую оказываются незащищенными добросовестные предприниматели.

В связи с чем, считаем целесообразным снизить размеры штрафов, установленных за указанные правонарушения, а также предусмотреть порядок и условия освобождения от административной ответственности юридических лиц, допустивших указанные нарушения непреднамеренно.

$$
* * *
$$

1. Трудовой кодекс Российской Федерации // Справочная правовая система «Консультан плюс».

2. Кодекс Российской Федерации об административных правонарушениях // Справочная правовая система «Консультан плюс».

3. Бредихин А.Л. Правоведение: учебное пособие. - Ростов-на-Дону: Феникс, 2015. - 253 с. 